\title{
Ethical Sensitivity of Business Students in Turkey: Truth or Myth
}

\author{
${ }^{*}$ F. Bahar Kurtulmusoglu' ${ }^{1}$, M. Mithat Uner ${ }^{2}$ \\ ${ }^{1}$ Baskent University Eskisehir, Baglica Kampusu, Ankara, Turkey \\ ${ }^{2}$ Gazi University Faculty of Economics and Administrative Sciences, Ankara, Turkey \\ *bahar@baskent.edu.tr
}

\begin{abstract}
This study examines the relationship between the ethical sensitivity scores of college students in relation with three focal points: the areas which they want to specialize, their intention about graduate education and the sectors they want to work. The samples are comprised of 740 junior, sophomore and senior business students at various universities located in Ankara, Turkey. The results indicate that there was a significant correlation between ethical sensitivity scores of the business students and the issues such as the areas which they want to specialize, their intention to have graduate degree and the sectors they plan to work.
\end{abstract}

Keywords: Business students, ethical sensitivity, graduate education, private sector, public sector

\section{Introduction}

There is an ongoing debate on the utility of ethic courses in the business curricula to improve the ethical decision making of the students. Besides, some of the researchers started to question the ethical erosion in recent years. The question is this stems from the education in business schools or not (Herndon, 1996). One of the alternatives proposed to improve the business ethics is the preparation guidance routes for organizational application and higher provision of upper management leadership. The second approach advocates teaching business ethics in business departments (Laczniak and Murphy, 1981). The ethical degradation in business world and practice of illegal application made it clear that the business schools should exert more efforts to ameliorate this situation by the use of education process (Wolfe and Fritsche, 1998). On the other hand, Carruth and Carruth (1991) claimed that ethical education would not be the answer for their individual ethical bottlenecks and would not suggest special behavior patterns but would do some evaluations to make some general proposals and give practical guides to solve these basic problems. Similarly, Browning and Zabriskie (1983) states that the ethical education should help the students to define the appropriate targets and to find suitable means to reach them.

In this respect, this study aims to shed light on the ethical sensitivity of the Turkish university students in relation to business discipline they want to specialize, their intention on having graduate degree and the sectors (public, private) they plan to work upon their graduation. As the debate about ethic courses is also current at universities in Turkey and the subject of business ethics has vital role in Turkey as a developing country, this study will help both academicians and practitioners. This paper is important because we believe it is the first paper to address these issues of ethical sensitivity of the Turkish university students in relation to their major, their intention on having graduate degree and the sectors (public, private) they plan to work upon their graduation. Understanding ethical sensitivity of the business students in relation with aforementioned variables could provide different perspectives for recruiters. This could be helpful for companies in their recruiting processes and strategies. This paper is organized in three main sections. The first section will introduce the reader to the scene through the literature review. The second section will set the stage on which the presents study is conducted by explaining the purpose of the study, methodology and the data analysis. Final section is designed as the part of the results and discussion of the study.

\section{Literature Review}

The appropriate evaluation and understanding of the attitudes of the management leaders of the future and providing them the necessary support require the correct analysis and guidance of the business students today. The studies on unethical behaviors of the administrators of the future are important guides for the solution of future administrative problems. The studies also show that the business schools are not successful enough to prepare their students to respond the arising complications in an ethical manner (Mcphail, 1999). The number of courses emphasizing ethics in business departments has risen in 
recent years. There is a continuing debate about whether the courses in business faculties' curricula improve the virtue of ethical decision. Some workers started to question whether the ethical erosion in recent years is the result of the lacking of ethical courses in business schools (Herndon, 1996). Even if the students were given an ethical education they would always have a chance to master the tricks and shortcuts of the administrative regulations. Since these tricks are present in textbooks, the students may have the misconception that they will be acceptably practiced in real life. The results obtained from the ethical studies of the students related to their fields are generally inconsistent (Tse \& $\mathrm{Au}, 1997)$. Chonko \& Hunt (1985) state that the educational area of the individual is a determining factor as regard to his/her perception of an ethical problem. It is claimed that business students are much more inclined to practice non-ethical means (Merritt 1991; Zinkhan et. al 1989; Lane 1995). Lane (1995) proves that the ethical levels of the business students varied with their areas of expertise. In Kelley et.al's study (1990) the marketing students have the lowest ethical scores among the business students. Jones (1991) determines that the students are much more protective as regards to administrative sources, when they chose to be employers and much more tolerant when they chose to be employees. Myrick (1972) reveals that the graduate business students have lower ethical levels. Similarly, Ugras and Borkowski (1992) showed that the undergraduate students have more ethical behaviors compared to the graduate students.

The studies carried out to determine the ethical levels of business students are basically based upon the determination of whether the business students' unethical behavior patterns differ according to the business discipline they want to specialize. Moreover, researchers also examine the relation between and the effects of the demographic factors and comparison of the ethical values of the business students and the administrative staff (Reiss and Mitra, 1998). Starting from that point, the research purpose is essentially based on three focal points:

- The relation between the ethical sensitivity scores and the business discipline students want to specialize.

- The relation between the ethical sensitivity scores and the students' intention of having graduate degree.

- The relation between the ethical sensitivity scores and sector (private, government) students want to work upon their graduation.

Concerning these three focal points, following hypothesis will be tested in the research:

H1: There is a relation between students' ethical sensitivity scores and the business discipline they are studying to specialize.

H2: There is a relation between students' ethical sensitivity scores and students' intention on having graduate degree

H3: There is a relation between students' ethical sensitivity scores and sector (private, government) they want to work

\section{Methodology}

The students were asked about the areas they would like to specialize, whether they were planning to have graduate education after having undergraduate degree and the prospective sectors they would like to work. There are four questions to determine the ethical values of the student who participated in to the study. There is an ethical sensitivity scale devised in order to determine the individual inclinations. The scale is formed with the use of scenario technique since it is stated to be the most suitable method in the measurement of ethical sensitivity (Finn et. al, 1993). The scenarios are taken from Ural (2003). The questions used in the determination of ethical sensitivity scores are based on the statements in Patterson's (2001) study (Scenario and questions can be seen in Appendix 1). The questions are asked with the use of seven points Likert -type scale.

The sample of the study was constituted by the sophomore, junior and senior business students studying in various universities located in Ankara $(N=740)$. Since freshman students do not take courses related to their respective fields they were not included in the study. Before conducting the survey, the total number of junior, sophomore and senior students of each faculty was obtained. Considering the number of students at each university, quota sampling was applied. This process produced 900 surveys, but 160 surveys were improperly completed. Therefore, there were a total of 740 usable responses for analysis purposes. The return rate was $75.3 \%$. Demographic profile of the respondents can be seen in Table 1. 
Table 1: Demographic Profile of the Respondents

\begin{tabular}{lll}
\hline Respondents $(\mathbf{n = 7 4 0 )}$ & & Percentage \\
\hline \multirow{3}{*}{ Gender } & Male & 51.2 \\
& Female & 48.8 \\
Year at the College & 2. & $22.7 \%$ \\
Age & 3. & $31.4 \%$ \\
& 4. & $45.9 \%$ \\
The field they wanted to specialize & $18-27$ & 100 \\
& Marketing & 38.4 \\
& Finance & 28.8 \\
& Accounting & 4.9 \\
The sectors they would like work & Management Organization & 4.3 \\
& Production & 9.9 \\
& MIS & 13.8 \\
The intention of doing graduate education & Private & $57.4 \%$ \\
& Public & $33 \%$ \\
& Indecisive & $9.6 \%$ \\
& No & $49.6 \%$ \\
\hline
\end{tabular}

\section{Results and Discussion}

Cronbach-Alpha coefficients were calculated for ethical sensitivity scale. This coefficient should not be less than 0.70 in order to accept a scale reliable (Nunnally, 1978). This value was 0.941 . The relation between the ethical sensitivity scores and the areas which the business students want to specialize, whether they think graduate education and the prospective sectors they want to work was tested with ANOVA test. The $\mathrm{p}$ values for all three situation were found as $(.00)<.05$ which shows that the relation between the ethical sensitivity scores and the areas which the business students want to specialize, whether they think graduate education and the prospective sectors they want to work was statistically significant. In order to signify these hoc Scheffe test was applied to all three situations.

There are significant differences between the ethical sensitivity scores between the students planning to work in public sector and the students want to work in the private sector after they completed their education. This was also the case between the students who wanted to work in the private sector and indecisive ones, and the student who wanted the work in the public sector and the indecisive ones. The ethical sensitivity scores of the students who wanted to work in the governmental sector after the completion of their education were higher than those of the students who wanted to work in the private sector. The mean score of ethical sensitivity of the students who were planning to work in the public sector was found to be higher than that of the indecisive ones. However, the mean ethical sensitivity value of the students who wanted to work in the private sector was lower than that of the indecisive ones (Table 2). Thus, H1, H2 and H3 are accepted.

Table 2: The mean significant difference analysis of the relation between the ethical sensitivity scores and the prospective areas which the students are planning to work

\begin{tabular}{llll}
\hline (I) Group & (J) Group & $\begin{array}{l}\text { Mean } \\
\text { Differences }\end{array}$ & Significance \\
\hline Private & Public & -.604 & $.000^{*}$ \\
& Indecisive & -.537 & $.025^{*}$ \\
Public & Private & .604 & $.000^{*}$ \\
& Indecisive & .067 & .949 \\
Indecisive & Private & .537 & $.025^{*}$ \\
& Public & -.067 & .949 \\
\hline
\end{tabular}

$* \mathrm{p} \leq 0.05$

There were statistically significant difference between the ethical sensitivity values of the students who intended to have graduate studies and the ones who did not have such an intention. Same case was valid between the ethical sensitivity scores of the students who intended to have graduate studies and the ones who were yet to make their minds about it. The mean ethical sensitivity value of the students who 
intended to have graduate degree was higher than that of the students who did not have such an intention. The mean ethical sensitivity value of the students who intended to have graduate degree on the other hand was lower than that of the indecisive ones (Table 3).

Table 3. The mean significant difference analysis of the relation between ethical sensitivity values and the students' intention to have graduate degree

\begin{tabular}{llll}
\hline (I) Group & (J) Group & Mean Differences & Significance \\
\hline No & Yes & -.723 & $.000^{*}$ \\
& Indecisive & -.605 & $.009^{*}$ \\
Yes & No & .723 & $.000^{*}$ \\
& Indecisive & .117 & .841 \\
Indecisive & Yes & .605 & $.009^{*}$ \\
& No & -.117 & .841 \\
\hline${ }^{*} \mathrm{p} \leq 0.05$ & & &
\end{tabular}

There were statistically significant differences between the ethical sensitivity values of the students who want to work in marketing and finance, marketing and management organization, marketing and production, and marketing and MIS sectors. The mean ethical value of the students who want to work in marketing sector after the completion of their education was lower than those of the students who want to work in the finance, management organization and MIS sectors (Table 4).

Table 4: The mean significant difference analysis of the relation between the ethical scores and the intention of the students to have graduate degree after the graduation

\begin{tabular}{|c|c|c|c|}
\hline (I) Group & (J) Group & Mean Differences & Significance \\
\hline \multirow[t]{5}{*}{ Marketing } & Finance & -.884 & $.000^{*}$ \\
\hline & Accounting & -.747 & .172 \\
\hline & Management Organization & -1.1 & $.010^{*}$ \\
\hline & Production & -.727 & $.021^{*}$ \\
\hline & MIS & -.664 & $.014^{*}$ \\
\hline \multirow[t]{6}{*}{ Finance } & Marketing & .884 & $.000^{*}$ \\
\hline & Accounting & .137 & .998 \\
\hline & Management & -.220 & .988 \\
\hline & Organization & & \\
\hline & Production & .157 & .989 \\
\hline & MIS & .220 & .919 \\
\hline \multirow{5}{*}{ Accounting } & Marketing & .747 & .172 \\
\hline & Finance & -.137 & .998 \\
\hline & Management Organization & -.358 & .967 \\
\hline & Production & .019 & 1 \\
\hline & MIS & .0825 & 1 \\
\hline \multirow[t]{5}{*}{ Management Organization } & Marketing & 1.10 & $.010^{*}$ \\
\hline & Finance & .220 & .988 \\
\hline & Accounting & .358 & .967 \\
\hline & Production & .378 & .926 \\
\hline & MIS & .441 & .841 \\
\hline \multirow[t]{5}{*}{ Production } & Marketing & .727 & $.021^{*}$ \\
\hline & Finance & -.157 & .989 \\
\hline & Accounting & -.0196 & 1 \\
\hline & Management Organization & -.378 & .926 \\
\hline & MIS & .0629 & 1 \\
\hline \multirow[t]{5}{*}{ MIS } & Marketing & .664 & $.014^{*}$ \\
\hline & Finance & -.220 & .919 \\
\hline & Accounting & -.082 & 1 \\
\hline & Management Organization & -.441 & .841 \\
\hline & Production & -.062 & 1 \\
\hline
\end{tabular}

${ }^{*} \mathrm{p} \leq 0.05$ 


\section{Conclusion and Recommendations}

The study revealed that the ethical sensitivity scores of the students were related to the business discipline they wanted to specialize, their intention having graduate degree and the prospective sectors they want to work after the graduation. In this context it became clear that the contents of the courses should be integrated with ethical values especially for the students who are planning to work in the marketing sector. The fact that the mean ethical sensitivity value of the students who wanted to work in the public sector was higher than that of the students who intended to work in the private. This can be attributed to the value given by the Turkish nation to the concept of state. In Turkish society the concept of working for the state is regarded more ethical than working for the individuals.

There is also a wide spread opinion that working for the private sector mainly serves for the maximization individual benefits. In this context, since working in the public sector is regarded more beneficial than working for private sector, it is normal that the ethical sensitivity values of the students who wanted to work in the private sector were lower than that of the ones who wanted to work in the public sector. It is apparent that this issue should be further investigated discussing the underlying reasons together with the political opinions of the individuals. Similarly, the fact that the ethical sensitivity mean value of the students who wanted to have graduate degree was higher than that of the ones who had no such intention was highly interesting. This can be explained with the fact that the value of the individuals give to education is directly related to ethical sensitivity. Also, the opinion that the doubts of people, who have higher, level of ethical sensitivity about the ethical issues of the business life, hinder their entrance into active working life should also be given serious consideration. Further studies related to this issue with a larger sample including the graduate students may reveal other factors. Also the study should be extended to different cultures in order to evaluate the cultural differences.

\section{References}

Borkowski, S. \& Ugras, Y. (1992). The Ethical Attitudes of Students as a Function of Age Sex and Experience. Journal of Business Ethics, 11(12), 961-979.

Browning, J. \& Zabriskie, B. (1983). How ethical are Industrial Buyers? Industrial Marketing Management, $12,219-224$.

Carruth, P. \& Carruth, A. (1991). Education in Ethics: The Role of Higher Education. Journal of Education for Business, 66(3), 168-172.

Chonko, L. \& Hunt, S. (1985). Ethics and Marketing Management an Empirical Examination. Journal of Business Research, 13, 339-359.

Finn, D., Shaub, M. \& Munter, P. (1993). The Effects of Auditors Ethical Orientation on Commitment and Ethical Sensitivity. Behavioral Research in Accounting, 5, 145-157

Herndon, N. (1996). A New Context for Ethics Education Objectives in a College of Business. Journal of Business Ethics, 15, 501-510.

Jones, T. (1991) Ethical Decision Making By Individuals In Organizations: An Issue Contingent Model. Academy of Management Review 16 (2), 366-395.

Kelley, S., Ferrell, W. \& Skinner, S. (1990). Ethical Behavior among Marketing Researcher, an Assessment of Selected Demographic Characteristics. Journal of Business Ethics, 9, 681-688

Lane, J. (1995). Ethics of Business Students: Some Marketing Perspectives. Journal of Business Ethics, 14 (8), 571-580.

Mcphail, K. (1999). The Threat of Ethical Accountants: An Application of Foucault's Concept of Ethics to Accounting Education and Some Thoughts on Ethically Educating For the Other. Critical Perspectives on Accounting, 10, 833-866

Merritt, S. (1991). Marketing Ethics and Education: Some Empirical Findings. Journal of Business Ethics, $10,625-632$

Laczniak, G \& Murphy, P. (1991). Fostering Ethical Marketing Decisions. Journal of Business Ethics, 10, 255-268

Myrick, F. (1975). Students Evaluations of the Ethics of Marketing Practices: The Role of Marketing Education. Proceedings from the Southern Marketing Association, 102-104.

Nunnally, J. (1978). Psychometric Theory. New York: McGraw Hill.

Patterson, D. (2001). Causal Effects of Regulatory Organizational and Personal Factors on Ethical Sensitivity. Journal of Business Ethics, 30(2), 123-160. 
Reiss, M. \& Mitra, K. (1998). The Effects of Individual Difference Factors on the Acceptability of Ethical and Unethical Workplace Behaviors. Journal of Business Ethics, 17, 1581-1593.

Shaub, M. (1989). An Empirical Examination of the Determinants of Auditors Ethical Sensitivity. Doctoral Dissertation. Texas.

Tse, A. \& Au, A. (1997). Are New Zealand Business Students More Unethical Than Non-Business Students? Journal of Business Ethics, 16, 445-450.

Ural, T. (2003). İşletme ve Pazarlama Etiği. Ankara: Detay Yayıncılık.

Wolfe, J. \& Fritsche, D. (1998). Teaching Business Ethics with Management and Marketing. Games Simulation and Gaming, 29 (1), 44-60.

Zinkhan, G. M., Bisesi, M. \& Saxton, M. J. (1989). MBAs' Changing Attitudes toward Marketing Dilemmas: 1981-1987. Journal of Business Ethics, 8, 963-974. 